\title{
LABORATORY STUDIES ON THE USE OF EICHHORNIA CRASSIPES IN TREATMENT SYSTEMS FOR SKIM LATEX SERUM
}

\author{
KRISHANTHI ABEYWICKRAMA ${ }^{1 *}$, P.A.J.Y APA ${ }^{1 * *}$ and KANTHI ABEYNAYAKE ${ }^{2}$ \\ ${ }^{1}$ Rubber Research Institute, Agalawatte. \\ ${ }^{2}$ Department of Botany, University of Colombo, Colombo.
}

(Received: 09 December 1994; accepted: 01 March 1996)

\begin{abstract}
The use of Eichhornia crassipes (water hyacinth) in conventional ponding systems for treatment of effluent from latex concentrate factories was investigated. Two types of skim serum were investigated using laboratory models of single and twin tank systems. BOD, COD \& $\mathrm{pH}$ of the two types of effluent could be brought down to permissible levels. A $100 \%$ reduction in BOD and over $80 \%$ reduction in COD for both types of serum were obtained with both single and twin tank systems after 10 days of running the system. A significant reduction in total solids content was also observed. The $10 \mathrm{~d}$ retention period in water hyacinth systems is a considerable improvement over the $22 \frac{1}{2} \mathrm{~d}$ retention period of conventional ponding systems.
\end{abstract}

Key words: Effluent, pollution control, rubber, skim latex, water hyacinth.

\section{INTRODUCTION}

Rubber factory effluents are known to cause serious environmental pollution problems if discharged without treatment. ${ }^{1}$ Malodour produced by untreated effluent as well as the pollution of natural waterways in rubber growing areas of natural rubber producing countries are of considerable concern. Effluent of latex concentrate factories are known to have a very much higher pollutant load than those released by crepe rubber and sheet rubber producing factories. ${ }^{1} \mathrm{BOD}$ (Biological Oxygen Demand) and COD (Chemical Oxygen Demand) values of $4458 \mathrm{mg} / \mathrm{l}$ and $6354 \mathrm{mg} / \mathrm{l}$ respectively have been reported for effluent from latex concentrate factories. ${ }^{2}$

Conventional or anaerobic facultative ponding systems are popular for treatment of effluents from sheet rubber and crepe rubber factories. ${ }^{3}$ Malodour caused by such ponding systems and the long effluent retention period of $22 \frac{1}{2} \mathrm{~d}$ which necessitates construction of large ponds requiring large land area, are the main problems associated with ponding systems although they are relatively simple to operate and maintain. Some of these drawbacks have been overcome by the introduction of Eichhornia crassipes (water hyacinth) plants into the

(Present addresses: " Department of Botany, University of Colombo, Colombo;

**Department of Botany, University of Sri Jayewardenepura, Nugegoda.)

This work formed part of the thesis submitted for the M.Phil. degree at University of Colombo by the first author. 
ponding system. ${ }^{4}$ Use of vascular aquatic plants has been reported by several workers to improve the efficiency of ponds by reducing the pollutants significantly. ${ }^{5-8}$ For rubber effluents, the retention time of $22 \frac{1}{2} \mathrm{~d}$ has been reduced to $10 \mathrm{~d}$ with satisfactory reductions on BOD and COD. (Kulatillake \& Yapa unpublished data) whilst John has reported a retention time of 10-15 d with water hyacinth. ${ }^{9}$ The reduction of the retention time means a reduction of the size of ponds which in turn reduces the land area requirement.

Oxidation ditch and rotating biodisc are two methods commonly used for treatment of effluents from latex concentrate factories..$^{10}$ These methods are highly capital intensive with high operational costs compared to ponding systems. It was therefore desirable to see if the improved version of ponding systems with water hyacinth (Kulatillake \& Yapa unpublished data), could be used for treatment of effluents from latex concentrate factories. The results of a series of laboratory scale trials, carried out for a period of two years are reported in this paper.

\section{METHODS AND MATERIALS}

All trials were carried out with effluent obtained from the latex concentrate plant at the Dartonfield Estate, Rubber Research Institute, Agalawatte. The process involved in the manufacture of latex concentrate is outlined in Fig. 1. Two different types of effluent from latex concentrate manufacture namely Type A and Type B were used; the main difference between the two being the preservative added to latex.

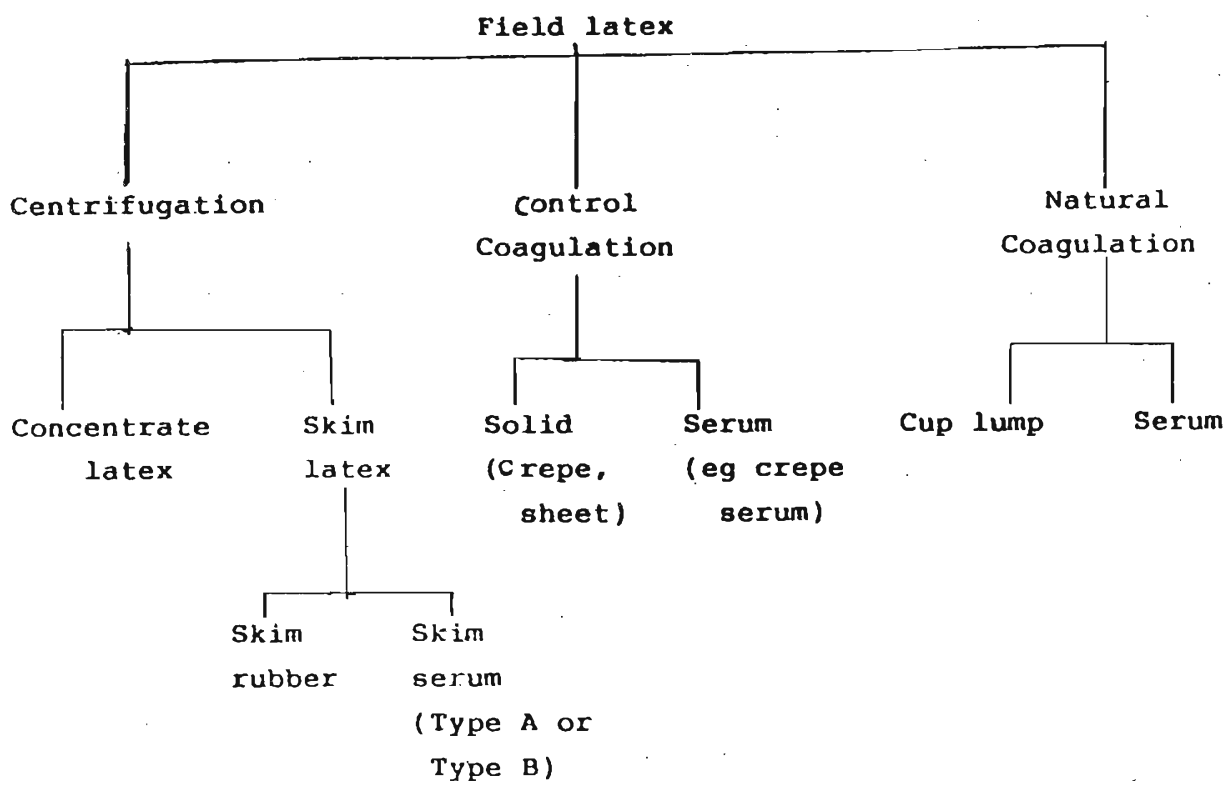

Figure 1: Methods of processing rubber latex into rubber coagulum. 
Type A skim serum was obtained by coagulation of skim latex resulting from high ammoniated centrifuged latex manufacture, using $10 \%$ sulphuric acid as the coagulant.

Type B skim serum was obtained from skim latex resulting from the manufacture of centrifuged latex preserved with low ammonia-TMTD (tetramethyl thiuramdisulphide) - $\mathrm{ZnO}$ - Sodium bisulphite; $5 \%$ formic acid being used as the coagulant.

Preliminary studies carried out with the two types of serum showed that they must be diluted with water at 1:20, 1:16 respectively prior to use in tanks, for good growth of water hyacinth plants and satisfactory removal of pollutants.

Two types of model treatment systems were investigated namely single tank treatment system ( glass tank, capacity $45 \mathrm{l}$ - Fig. 2) and twin tank treatment system ( two glass tanks of 451 capacity each connected as in Fig 2). A single tank treatment system consisting of a cylindrical plastic tank with a capacity of $18 \mathrm{l}$ and comparatively deeper than glass tanks, was also tested since such deep tanks provide better anaerobic conditions with little or no sunlight, than glass tanks used in this study.

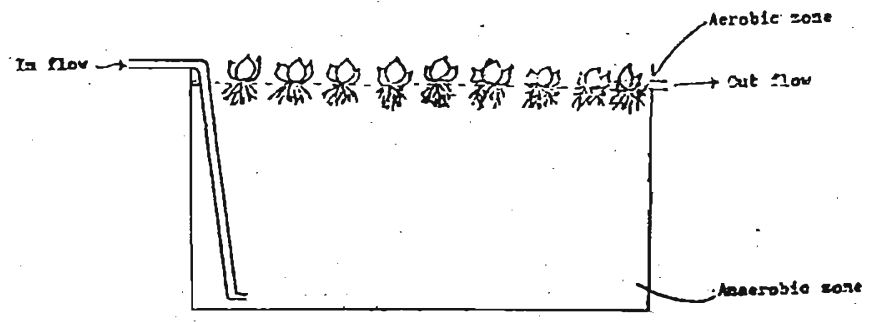

(2)

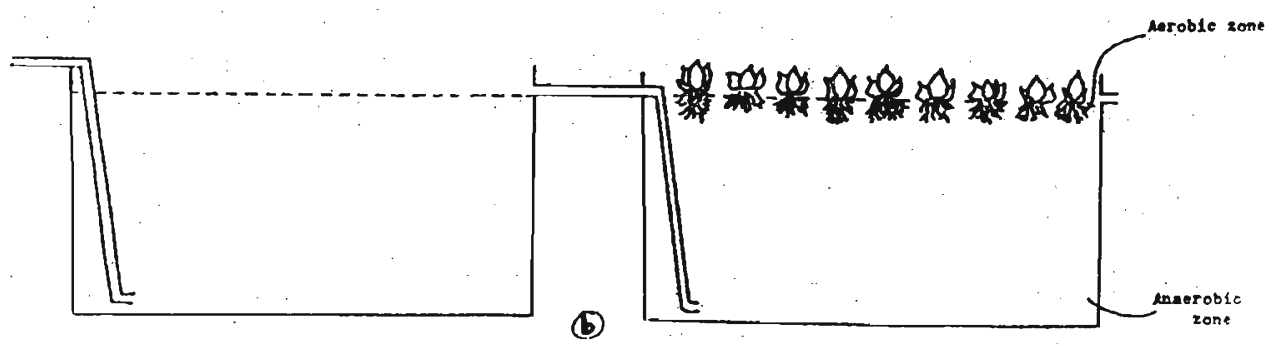

Figure 2: Diagram of single tank system (a) and twin tank system (b) with water hyacinth. 
In a typical run in a single tank system (glass), $40 \mathrm{l}$ of appropriately diluted serum wereintroduced into the tank and allowed to stand for $10 \mathrm{~d}$ for adjustment of pH between $6-7$ (pre-conditioning). Ten healthy water hyacinth plants were introduced into the tank on the 10th day; the control system had no plants. From the 10th day, 4.51 of diluted fresh serum of the appropriate type were introduced slowly to the bottom of the respective tank daily, using funnels fitted with rubber tubes (Fig. 2). Samples of final discharge from each system were tested once in $5 \mathrm{~d}$ for BOD, COD, total solids and $\mathrm{pH}$ for a period of $40 \mathrm{~d}$.

In a typical run in a twin tank system, the two tanks were filled with $40 \mathrm{l}$ each of appropriately diluted serum and pre-conditioned as above. Plants were introduced into the second tank on the 10th day. Fresh serum, appropriately diluted with water, was introduced into the first tank from the 10th day onwards, daily as described before.

In a typical run with single tank (plastic) systems, tanks were filled with 181 of appropriately diluted serum and $500 \mathrm{~g}$ of fresh cowdung was added into each followed by a pre-conditioning period of $10 \mathrm{~d}$ after which water hyacinth plants (five plants each) were introduced. Sampling was done as described before.

A combination of the permanganate-sodium azide modification of the Winkler method was adopted for the determination of BOD. ${ }^{11}$ The dichromate reflux method was used for the determination of COD. ${ }^{11}$ The method of Zaid et al. was used to determine the total solids content (TS) of serum samples. ${ }^{11}$

\section{RESULTS}

Properties of skim serum: Typical properties of the two types of skim serum are given in Table 1. Both types had a low $\mathrm{pH}$ as expected due to the addition of acid for coagulation. Of the two types of skim serum Type A had a considerably higher pollutant load than Type B with respect to the parameters COD, TS and Total nitrogen except for BOD. Variability between samples of both Type A and Type B serum was found to be considerably high (Table 1).

\section{Studies with single tank (plastic) system:}

$p H$ : The $\mathrm{pH}$ of the final discharge from the single tank system for Type A was well within the permissible level whilst that of Type B was slightly less (Table 2). 
Table 1: Average properties of two types of skim serum (undiluted).

\begin{tabular}{ccc}
\hline Property & Type A & Type B \\
\hline $\mathrm{pH}$ & $4.12 \pm 0.80$ & $4.51 \pm 0.68$ \\
BOD & $4800 \pm 1100$ & $5200 \pm 1050$ \\
& & \\
COD & $32600 \pm 16900$ & $5590 \pm 2560$ \\
TS & & \\
& $50600 \pm 26900$ & $2800 \pm 4450$ \\
Total-N & $5700 \pm 3800$ & $4090 \pm 760$ \\
\hline
\end{tabular}

All values except $\mathrm{pH}$ are expressed in $\mathrm{mg} / \mathrm{l}$. Mean values of six different samples; \pm standard deviation are given.

BOD: BOD in Type A skim serum initially showed an increase and then decreased to $0 \mathrm{ppm}$ with occasional fluctuations. The system appeared to take about $10 \mathrm{~d}$ to get stabilized after which it gave a mean value of $75 \mathrm{mg} / \mathrm{l}$ until the 40th day. BOD of Type B skim serum fluctuated slightly initially, a slight decrease at the beginning and then an increase, before it dropped to $0 \mathrm{ppm}$. Mean value for Type B skim serum was well within the permissible level. A 100\% reduction in BOD was observed for both types of serum investigated (Table 2).

COD: COD in Type A skim serum fluctuated around 1000 - 2500 ppm before it dropped to low levels. COD in Type B skim serum showed a drastic decrease at the beginning, reaching a low level which continued to be so until the end of the experiment. Maximum reduction in COD was seen in Type B skim serum which was as high as $93 \%$ compared to $72 \%$ of Type A (Table 2 ).

Total solids: Total solids of both types of serum showed an increase at the initial stages and then gradually decreased until the end of the experiment. The mean values of both Type A and Type B for the experimental period of $40 \mathrm{~d}$ were well within the permissible level of $1500 \mathrm{mg} / 1$ (Table.2). 
Table 2: Effect of water hyacinth on BOD, COD and TS in single tank treatment systems (plastic) for different types of rubber serum.

\begin{tabular}{|c|c|c|c|}
\hline \multirow[t]{2}{*}{ Test } & \multirow[t]{2}{*}{ Period } & \multicolumn{2}{|c|}{ Type of serum } \\
\hline & & Type A & Type B \\
\hline \multirow[t]{4}{*}{ BOD } & 0 day & 730 & 370 \\
\hline & 40th day & 0 & 0 \\
\hline & $\%$ reduction & 100 & 100 \\
\hline & Mean (10-40d) & $75 \pm 130$ & $47 \pm 91$ \\
\hline \multirow[t]{4}{*}{ COD } & 0 day & 1440 & 3400 \\
\hline & 40th day & 400 & 220 \\
\hline & $\%$ reduction & 72 & 93 \\
\hline & Mean (10-40d) & $507 \pm 247$ & $367 \pm 180$ \\
\hline \multirow[t]{4}{*}{ TS } & 0 day & 3395 & 1001 \\
\hline & 40th day & 435 & 547 \\
\hline & $\%$ reduction & 89 & 45 \\
\hline & Mean $(10-40 d)$ & $796 \pm 696$ & $829 \pm 221$ \\
\hline \multirow[t]{3}{*}{$\mathrm{pH}$} & 0 day & 6.7 & 6.4 \\
\hline & 40th day & 6.6 & 6.3 \\
\hline & Mean (10-40d) & $6.4 \pm 0.43$ & $6.3 \pm 0.09$ \\
\hline
\end{tabular}

All values expressed in $\mathrm{mg} /$, results represent two separate runs of the system.

\section{Studies with single and twin tank (glass) systems:}

$p H$ : A decrease in $\mathrm{pH}$ was observed in both skim serum $\mathrm{A}$ and $\mathrm{B}$ at the beginning of the experiment and again an increase after the 5 th day and remained between $\mathrm{pH} 6$ - 7 until the end of the experiment. The mean $\mathrm{pH}$ of Type A serum for the entire $40 \mathrm{~d}$ run of both single (6.2) and twin tank (6.2) system were slightly less than the permissible range of 6.5-8.0. However, the $\mathrm{pH}$ of Type B serum in both systems was satisfactory, being within the permissible range.

COD: In single tank systems the COD removal was $87 \%$ for Type A and $91 \%$ for Type B with mean values well within the permissible limit of $400 \mathrm{mg} / \mathrm{l}$ (Table 3 ). COD removal in the twin tank system too was satisfactory with mean values within the permissible level (Table 3 ). 
Table 3: Comparison of performance of single and twin tank systems (glass) with water hyacinth for Type A and Type $B$ serum.

\begin{tabular}{|c|c|c|c|c|c|}
\hline \multirow{3}{*}{$\begin{array}{l}\text { Test } \\
\text { BOD }\end{array}$} & \multirow{3}{*}{$\begin{array}{l}\text { Period } \\
\text { o day }\end{array}$} & \multicolumn{2}{|c|}{ Single tank } & \multicolumn{2}{|c|}{ Twin tank } \\
\hline & & \multicolumn{2}{|c|}{ Type A Type B } & Type A & \multirow{2}{*}{$\frac{\text { Type B }}{2030}$} \\
\hline & & 220 & 1120 & 455 & \\
\hline & 40th day & 0 & 0 & 0 & 0 \\
\hline & $\%$ reduction & 100 & 100 & 100 & 100 \\
\hline & Mean (10-40d) & $62 \pm 61$ & $42 \pm 49$ & $18 \pm 45$ & $95 \pm 233$ \\
\hline \multirow[t]{4}{*}{$\mathrm{COD}$} & 0 day & 1200 & 1760 & 1200 & 4720 \\
\hline & 40th day & 160 & 160 & 170 & 80 \\
\hline & $\%$ reduction & 87 & 91 & 84 & 98 \\
\hline & Mean (10-40d) & $206 \pm 157$ & $390 \pm 375$ & $266 \pm 145$ & $243 \pm 206$ \\
\hline \multirow{5}{*}{$\mathrm{TS}$} & & . & & & \\
\hline & 0 day & 4993 & 5008 & 5789 & 5005 \\
\hline & 40th day & 2796 & 497 & 2637 & 634 \\
\hline & $\%$ reduction & 43 & 90 & 54 & 87 \\
\hline & Mean $(10-40 \mathrm{~d})$ & $2308 \pm 163$ & $775 \pm 336$ & $2392 \pm 59$ & $716 \pm 289$ \\
\hline \multirow[t]{3}{*}{$\mathrm{pH}$} & 0 day & 5.8 & 4.8 & 5.7 & 4.2 \\
\hline & 40th day & 6.1 & 6.8 & 6.0 & 6.7 \\
\hline & Mean (10-40d) & $6.2 \pm 0.19$ & $6.6 \pm 0.25$ & $6.2 \pm 0.13$ & $6.8 \pm 0.16$ \\
\hline
\end{tabular}

All values except $\mathrm{pH}$, expressed in $\mathrm{mg} / \mathrm{l}$, results represent two separate runs of the system.

$B O D$ : The single tank system gave a $100 \%$ reduction in BOD from the 9 th day onwards with occasional fluctuations for both Type A \& Type B skim serum. A similar reduction in BOD was observed in the twin tank system for Type A skim serum (Table 3). However, the fluctuations in the twin tank system with Type B serum occurred relatively frequently resulting in a slightly higher mean value.

Total solids: The removal of total solids in the single tank system were $43 \%$ and $90 \%$ respectively for Type A and Type B serum on the 40 th day. The mean value for Type A serum was well above the permissible level of $1000 \mathrm{mg} / \mathrm{l}$ whilst that of Type B was within the permissible level. A similar pattern was observed in the twin tank system where Type A did not satisfy the standard whilst Type B was within the permissible level (Table 3 ). The high Total solid content of Type A skim serum in both single and twin tank systems were apparently due to the luxurious growth of algae in them and this algae came off with the final discharge, giving it a greenish colour. 
Table 4: Tolerance limits introduced by Govt. of Sri Lanka, for effluents from rubber factories discharged into inland surface waters. ${ }^{12}$

\begin{tabular}{lcc}
\hline Determinant & \multicolumn{2}{c}{ Tolerance limit } \\
Type 1 & $\begin{array}{c}\text { Type } 2 \\
\text { factories }\end{array}$ & $6.5-8.5$ \\
factories & $6.5-8.5$ & 100 \\
Total suspended solids & 100 & 1000 \\
Total solids & 1500 & 50 \\
BOD ${ }_{5}$ at $20^{\circ} \mathrm{C}$ & 60 & 400 \\
COD & 400 & 60 \\
Total nitrogen & 300 & 40 \\
Ammoniacal $\mathrm{N}$ & 300 & 2 \\
\hline Sulphides & 2 & 2 \\
\hline
\end{tabular}

Type 1 factories -Latex concentrate

Type 2 factories - Standard Lanka Rubber, crepe rubber, ribbed smoked sheets All values except $\mathrm{pH}$ expressed in $\mathrm{mg} / \mathrm{l}$

\section{DISCUSSION}

The results of this study reveal that water hyacinth is effective in removing organic pollutants from both Type A and Type B skim serum. The reduction of BOD was $100 \%$ for both types of serum investigated. A similar reduction for crepe rubber serum has been observed by Kulatillake \& Yapa (unpublished data). Sethu showed that a $98 \%$ removal of BOD of Type A skim serum can be obtained after a retention time of $76 \mathrm{~d}$ in anaerobic facultative ponds. ${ }^{10}$ The $10 \mathrm{~d}$ retention period of this study using water hyacinth is therefore a considerable improvement.

Pre-conditioning of serum for $10 \mathrm{~d}$ was an important requirement for natural adjustment of $\mathrm{pH}$ to near neutral thus eliminating the necessity for addition of chemicals for $\mathrm{pH}$ adjustment. Growth of water hyacinth has been best observed at a narrow range of $\mathrm{pH}$ 5.0-7:5. ${ }^{4}$ However, in the present study, a good growth of water hyacinth plants was always observed above $\mathrm{pH}$ 6.0. Environmental standards ${ }^{12}$ require acidic rubber effluents to be raised to a $\mathrm{pH}$ range of $6.5-8.5$ which is achieved by the treatment system adopted in this study. Type A skim serum, however, did not satisfy the standards presumably due to excess acid 
used for coagulation. Of the two types of skim serum, Type A skim serum was also found difficult to pre-condition, presumably due to high level of ammonia used as a preservative.

Dilution of serum was found to be another major requirement for survival and good growth of water hyacinth plants in both Type A and Type B skim serum. The dilution rate required for Type A skim was 1:20 whereas it was 1:16 minimum for Type B skim serum compared to 1:6 dilution required for crepe serum as observed by Kulatillake \& Yapa (unpublished data). Dilution and preconditioning of serum which were found to be two critical factors, have not been reported by previous workers. ${ }^{4,10}$ Pre-conditioning of serum is necessary only at the beginning, i.e. at the time of setting up of the treatment system after which diluted fresh serum can be introduced into the treatment system as it should be, if the system is to be of any practical value.

Of the two systems investigated both single tank and twin tank systems were equally effective in removal of pollutants in rubber serum. Reduction of BOD was very often $100 \%$ and COD reduction above $84 \%$. The only parameter which requires further attention was the total solids content of Type A skim serum of which the reductions were only $43 \%$ in single tank system and $54 \%$ in twin tank system; the respective mean values being $2308 \mathrm{mg} / \mathrm{l}$ and $2392 \mathrm{mg} / \mathrm{l}$ which are well above the permissible level of $1000 \mathrm{mg} / \mathrm{l}$. Luxurious growth of algae in situations of high $\mathrm{N}$ and $\mathrm{P}$ contents, has been reported to lead to increased total solids contents. ${ }^{7}$ Type A serum with which this high TS content was encountered, usually has a comparatively higher nitrogen content (unpublished data). In addition, the ready exposure of surface layers of glass tanks with Type A serum, also would have enhanced algal growth. The reduced TS in Type A serum of plastic tanks also points to the role of sunlight in algal growth in glass tank systems (Table 2). Higher TS content can therefore be avoided in practical applications. TS has been successfully reduced using water hyacinths in block rubber effluent ${ }^{2}$ and in wastewater lagoons. ${ }^{8}$ Type B skim serum gave a satisfactory reduction in TS level in single and twin tank systems, in both glass and plastic (Table $2 \& 3$ ).

The results of this study indicate that single tank and twin tank systems are equally effective in removing organic pollutants with regard to all three parameters investigated namely BOD, COD and TS. This was further confirmed by the findings of the trial carried out in plastic tanks (Table 2). The finding that single tank systems are as effective as twin tank systems is of great practical value since it reduces the land area requirement for construction of ponds. Preliminary investigations showed that Total Nitrogen and Ammoniacal . Nitrogen content were also satisfactory in water hyacinth systems (unpublished data). 
The findings of this study clearly indicates that a water hyacinth system with a $10 \mathrm{~d}$ retention period similar to that used for crepe rubber factory effluents (Kulatillake \& Yapa - unpublished data) can be adopted for skim serum as well. The reduction in the retention period of $22 \frac{1}{2} \mathrm{~d}$ of conventional anaerobic facultative ponding systems to $10 \mathrm{~d}$ is another added advantage of water hyacinth systems. In addition there was no malodour which is usually associated with conventional ponding systems where no water hyacinths are used.

It was observed that Type.B skim serum could be easily treated with both single and twin tank systems. A satisfactory reduction in TS of Type B was obtained in both systems whereas TS of Type A skim serum was above permissible level (Table 3). Typical properties of Type B skim serum indicate that the pollutant load of Type B serum is low compared to that of Type A skim serum. It appears therefore that the choice of preservative system can also be used to reduce the degree of pollution in latex concentrate manufacturing industry.

\section{Acknowledgement}

A research grant from the Natural Resources Energy and Science Authority of Sri Lanka ( RG/AG/86/4). and the help of staff from the Biochemistry Department of the RRI are acknowledged.

\section{References}

1. Yapa P.A.J. (1984). Effluent disposal and environmental pollution in rubber plantations in Sri Lanka. Proceedings of the International Rubber Conference Colombo, 1984, 2: 381-391. Rubber Research Institute of Sri Lanka, Agalawatte, Sri Lanka.

2. Dolmat M.T., Karim M.Z., Iza Z. \& Pillai K.R. (1979). Land disposal of rubber factory effluent: its effect on soil properties and performance on rubber and oil palm. Proceedings of the Rubber Research Institute of Malaysia Planters Conference, 1979, Kuala Lumpur, 436-457.

3. Ibrahim A. (1980). Start up anaerobic/facultative ponds for treatment of rubber processing effluents. Planters Bulletin,Rubber Research Institute of Malaysia 165: 153 - 155

4. John C.K. (1984). Treatment of agroindustrial wastes using water hyacinth. Water Science \& Technology 17: 781 - 790 
5. Wolverton B.C.(1982). Hybrid waste water treatment system using anaerobic microorganisms and reed (Phragmitis communis) Economic Botany 36: 29-30.

6. Wolverton B.C., Barlow R.M. \& McDonald R.C. (1976). Application of: vascular aquatic plants for pollution removal, energy and food production in a biological system In: Biological Control of Water Pollution (Eds. J.Tourbier \& R.W.Pierson). Univ. of Pennsylvania Press, p. 141.

7. Wolverton B.C. \& McDonald R.C. (1979). Upgrading facultative lagoons with aquatic vascular plants. Journal of Water Pollution Control Federation 51: 305-313.

8. Rogers H.H. \& Davis D.E. (1972). Nutrient removal by water hyacinths. Weed Science 20: 423-428.

9. John C.K. (1983). Use of water hyacinth in the treatment of effluents from rubber industry. Proceedings of International Conference on water hyacinth, Hyderabad, India, 1983,p. 699-712. United Nations Environment Programme, Nairobi, Kenya.

10. Sethu S.(1977). Effluent discharge from latex concentrate factories. Proceedings of the Rubber Research Institute Malaysia, Planters Conference, Kuala Lumpur, Malaysia, 1977, p. 217 - 229.

11. Zaid I., Yong W.M. \& Singh M.M. (1980). Manual of laboratory methods for chemical analysis of rubber effluents. RRI Malaysia, Kuala Lumpur, Malaysia, p. $1-21$.

12. Anon (1990) National Environment Act of Sri Lanka No 47 of 1980 as amended by act No 56 of 1988 and gazetted on 08.01.1990.

13. Boyd C.E.(1969). The nutritive value of three species of water weeds. Economic Botany 23: 123-127. 